\title{
Kidney Cancer pNX TNM Finding v6 and v7
}

National Cancer Institute

\section{Source}

National Cancer Institute. Kidney Cancer pNX TNM Finding v6 and v7. NCI Thesaurus.

Code C63571.

Kidney cancer in which the regional lymph nodes cannot be assessed. (from AJCC 6th and 7th Eds.) 